\section{Outpatient chronic obstructive pulmonary disease rehabilitation}

\section{La réadaptation de la maladie pulmonaire obstructive chronique en milieu ambulatoire}

$\mathrm{N}$ ormally, this space is devoted to discussion of a paper in the current issue of the Canadian Respiratory Journal, but on this occasion, I write to draw attention to an important paper published elsewhere. In a recent issue of Annals of Internal Medicine, a large Canadian group announced the results of a home-based pulmonary rehabilitation program for patients with chronic obstructive pulmonary disease (COPD), as compared with the standard hospital-based model (1). In short, patients underwent exercise at home as opposed to in the hospital, and achieved similar results in terms of disease-specific quality of life and some meas-

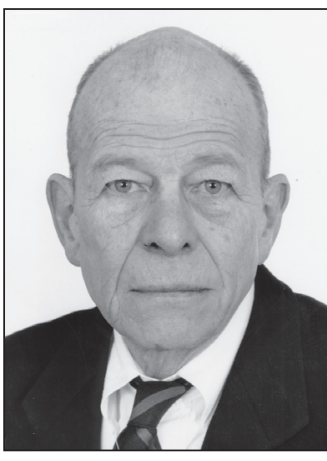

Nick R Anthonisen
Tormalement, cette chronique est consacrée à 1 un article publié dans le numéro courant de la Revue canadienne de pneumologie, mais cette fois-ci, je tiens à attirer votre attention sur un article important publié ailleurs. Dans un récent numéro des Annals of Internal Medicine, un grand groupe canadien a annoncé les résultats d'un programme de réadaptation pulmonaire à domicile destiné aux patients atteints d'une maladie pulmonaire obstructive chronique (MPOC) par rapport au modèle standard en milieu hospitalier (1). En résumé, les patients ont effectué des exercices à domicile plutôt qu'à l'hôpital et obtenu des résultats ures of exercise capacity that were durable in that they persisted for a year of follow-up.

This is important news and has the potential to change the state of the art. It has been repeatedly documented that respiratory rehabilitation can produce major benefits in terms of quality of life and exercise tolerance in COPD patients $(2,3)$, and that such programs are not widely available, being largely based at teaching hospitals and reaching approximately $1 \%$ to $2 \%$ of Canadian COPD patients (4). Clearly, making rehabilitation more accessible would be a major improvement in care, and the paper by Maltais et al (1) indicates that this is a possibility.

It is possible but not certain that the results of the Maltais trial will be widely adopted with success, simply because it was a trial, and trials often do not mimic normal care patterns. To compare the hospital-based and home-based groups fairly, both exercise programs were executed with considerable effort. Both groups had an initial intensive four-week hospital-based education package that included familiarization with the exercise protocols (5). The eight-week home and hospital exercise programs were standardized, and the latter was supervised closely. After the rehabilitation, patients were asked to continue to exercise three times per week and were followed closely with periodic telephone checks. Finally, the clinical centres involved in the study provided ready telephone access for the patients in the study (1).

This trial had an excellent design. Both programs were examples of the best possible practice. The control (hospitalbased) group received the best program that the expert investigators could design with the expectation that it would produce the best result possible. The home-based program differed from the control group only in terms of the site of the exercise program, with a minor adjustment in exercise intensity. The hospital-based program produced the expected beneficial results, so the fact that the results of the home-based program were equivalent cannot be ascribed to a failure in the control arm of the study. similaires pour ce qui est de la qualité de vie propre à la maladie et de certaines mesures durables de capacité à l'exercice, qui ont persisté pendant l'année de suivi.

C'est une nouvelle importante qui pourrait modifier les normes. Il est largement documenté que la réadaptation respiratoire peut apporter d'importants bienfaits en matière de qualité de vie et de tolérance à l'exercice chez les patients atteints de $\operatorname{MPOC}(2,3)$ et que ces programmes ne sont pas généralisés puisqu'ils sont surtout offerts dans des hôpitaux d'enseignement et qu'ils atteignent environ $1 \%$ à $2 \%$ des patients canadiens atteints d'une MPOC (4). De toute évidence, si la réadaptation devenait plus accessible, les soins s'en trouveraient considérablement améliorés, et l'article de Maltais et coll. (1) indique que cette possibilité existe.

Il est possible, mais pas certain, que les résultats de l'essai de Maltais soient largement adoptés avec succès, simplement parce qu'il s'agit d'un essai et que les essais n'imitent pas les schèmes de soins normaux. Pour comparer le groupe hospitalisé au groupe à domicile de manière juste, de grands efforts ont été ménagés pour les deux programmes d'exercices. Les deux groupes ont d'abord reçu une formation intensive de quatre semaines en milieu hospitalier, incluant une familiarisation aux protocoles d'exercices (5). Les programmes d'exercices de huit semaines à domicile et en milieu hospitalier étaient standardisés, et le programme en milieu hospitalier était étroitement supervisé. Après la réadaptation, les patients ont été invités à poursuivre les exercices trois fois par semaine et ont profité d'un suivi étroit par vérification téléphonique périodique. Enfin, les centres cliniques participants ont assuré un accès téléphonique immédiat aux patients à l'étude (1).

Cet essai avait une excellente méthodologie. Les deux programmes étaient des exemples de pratique exemplaire. Le groupe témoin (hospitalisé) a reçu le meilleur programme que les chercheurs pouvaient concevoir, dans l'attente qu'ils obtiennent les meilleurs résultats possible. Le programme à domicile différait de celui du groupe témoin seulement en ce 
On the other hand, duplicating either of the programs of Maltais et al (1) would be a tall order for most centres, regardless of their location. Furthermore, their results speak to an extraordinary level of dedication on the part of both patients and staff. Approximately $80 \%$ of randomly assigned patients were evaluated one year after the inception of their programs; for a study of this kind, the dropout rate was very low. Obviously, Maltais et al (1) deserve hearty congratulations. Although duplicating their programs may be difficult or impossible, their message is that home exercise programs can achieve the same results as those based in hospitals, provided they are implemented with conviction. This finding should make exercise rehabilitation of COPD patients more accessible in Canada.

\section{REFERENCES}

1. Maltais F, Bourbeau J, Shapiro S, et al. Effects of home-based pulmonary rehabilitation in patients with chronic obstructive pulmonary disease. Ann Int Med 2008;149:869-78.

2. Lacasse Y, Goldstein R, Lasserson TJ, Martin S. Pulmonary rehabilitation for chronic obstructive pulmonary disease. Cochrane Database Syst Rev 2006:CD003793.

3. Nici L, Donner C, Wouters E, et al. American Thoracic Society/ European Respiratory Society statement on pulmonary rehabilitation. Am J Respir Crit Care Med 2006;173:1390-413.

4. Brooks D, Sottana R, Bell B, et al. Characterization of pulmonary rehabilitation programs in Canada in 2005. Can Respir J 2007;14:87-92.

5. Bourbeau J, Julien M, Maltais F, et al. Reduction of hospital utilization in patients with chronic obstructive pulmonary disease: A diseasespecific self-management intervention. Arch Int Med 2003;163:585-91. qui a trait au lieu du programme d'exercices et à un rajustement mineur à l'intensité de l'exercice. Le programme en milieu hospitalier a donné les résultats bénéfiques escomptés. Le fait que les résultats du programme à domicile aient été équivalents ne peut donc pas être attribué à un échec du volet témoin de l'étude.

Par contre, la plupart des centres éprouveraient de la difficulté à reproduire l'un des programmes de Maltais et coll. (1), quel que soit leur lieu. De plus, leurs résultats exigent une volonté extraordinaire, tant de la part des patients que du personnel. Environ 80 \% des patients affectés au hasard ont été évalués un an après le début de leur programme. Pour une étude de ce type, le taux d'abandon était très faible. De toute évidence, Maltais et coll. (1) méritent de chaleureuses félicitations. Même s'il était difficile, voire impossible, de reproduire leurs programmes, les conclusions démontrent qu'un programme d'exercices à domicile peut obtenir les mêmes résultats qu'en milieu hospitalier, pourvu qu'il soit implanté avec conviction. Ces observations devraient favoriser l'accès à la réadaptation à l'exercice pour les patients atteints d'une MPOC au Canada.

\section{RÉFÉRENCES}

1. Maltais F, Bourbeau J, Shapiro S et coll. Effects of home-based pulmonary rehabilitation in patients with chronic obstructive pulmonary disease. Ann Int Med 2008;149:869-78.

2. Lacasse Y, Goldstein R, Lasserson TJ, Martin S. Pulmonary rehabilitation for chronic obstructive pulmonary disease. Cochrane Database Syst Rev 2006:CD003793.

3. Nici L, Donner C, Wouters E et coll. American Thoracic Society/ European Respiratory Society statement on pulmonary rehabilitation. Am J Respir Crit Care Med 2006;173:1390-413.

4. Brooks D, Sottana R, Bell B et coll. Characterization of pulmonary rehabilitation programs in Canada in 2005. Can Respir J 2007;14:87-92.

5. Bourbeau J, Julien M, Maltais F et coll. Reduction of hospital utilization in patients with chronic obstructive pulmonary disease: A disease-specific self-management intervention. Arch Int Med 2003;163:585-91. 


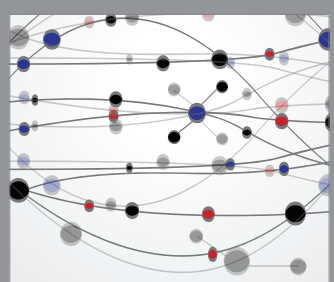

The Scientific World Journal
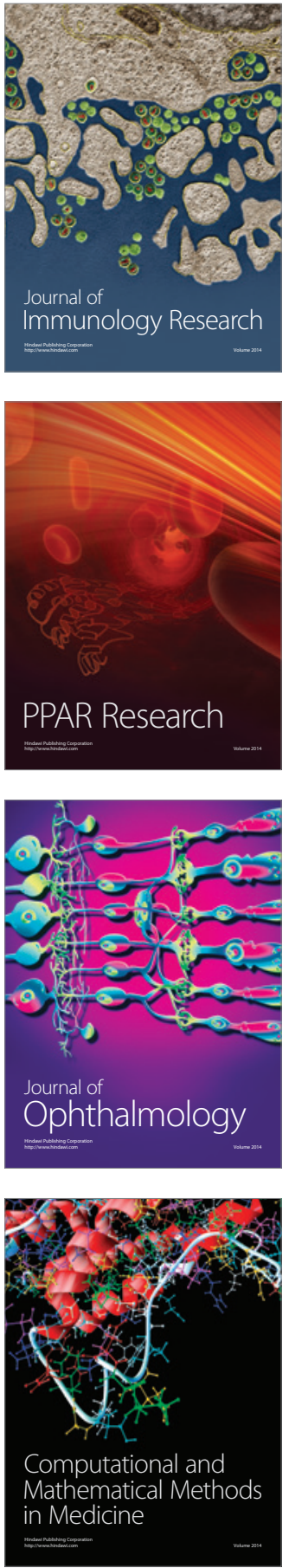

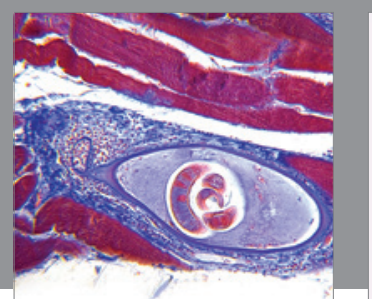

Gastroenterology Research and Practice

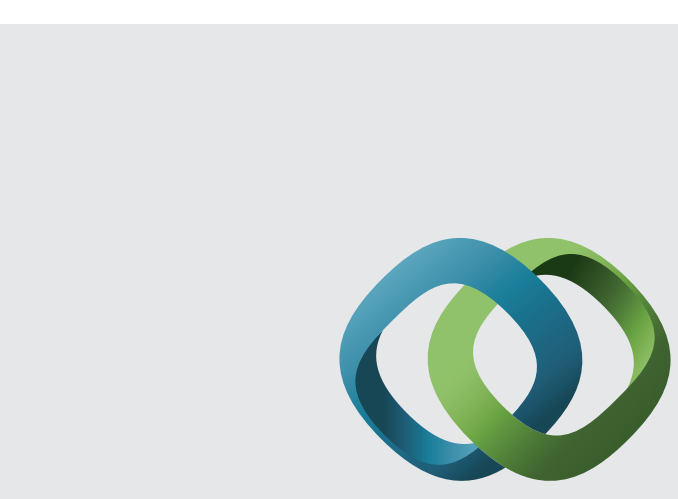

\section{Hindawi}

Submit your manuscripts at

http://www.hindawi.com
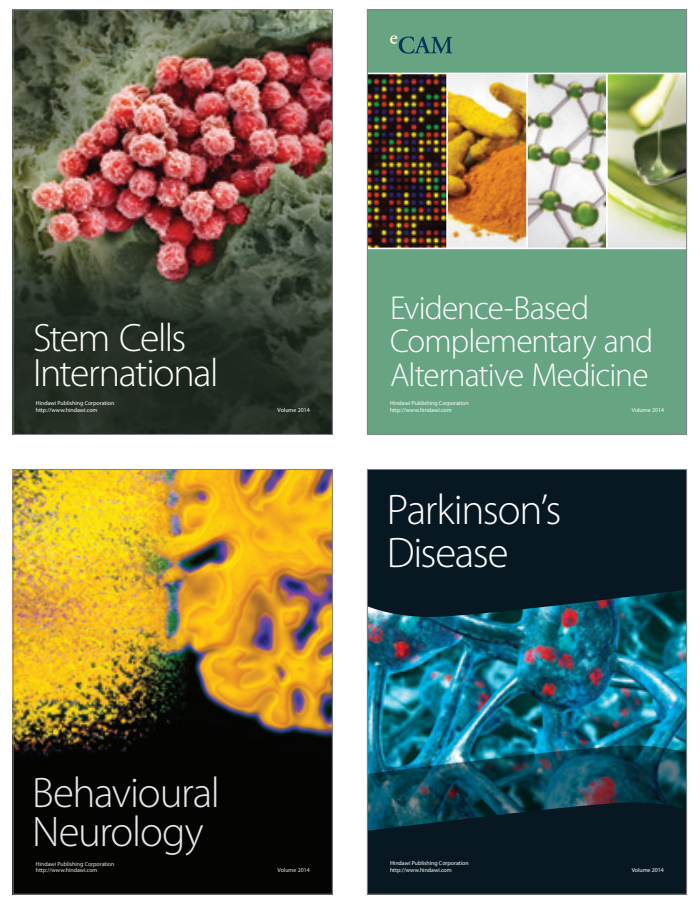
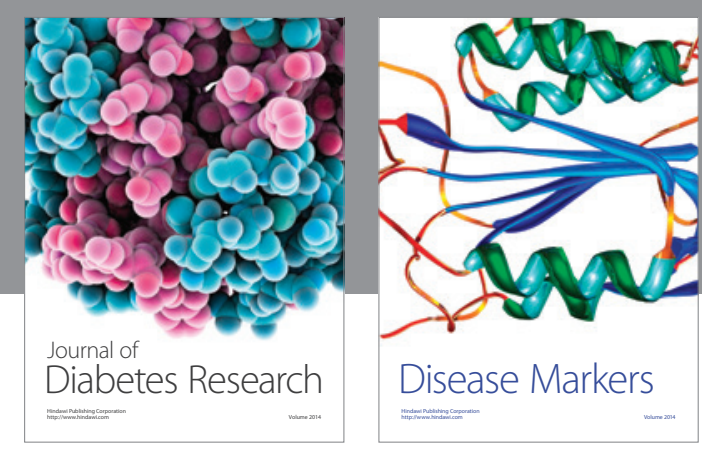

Disease Markers
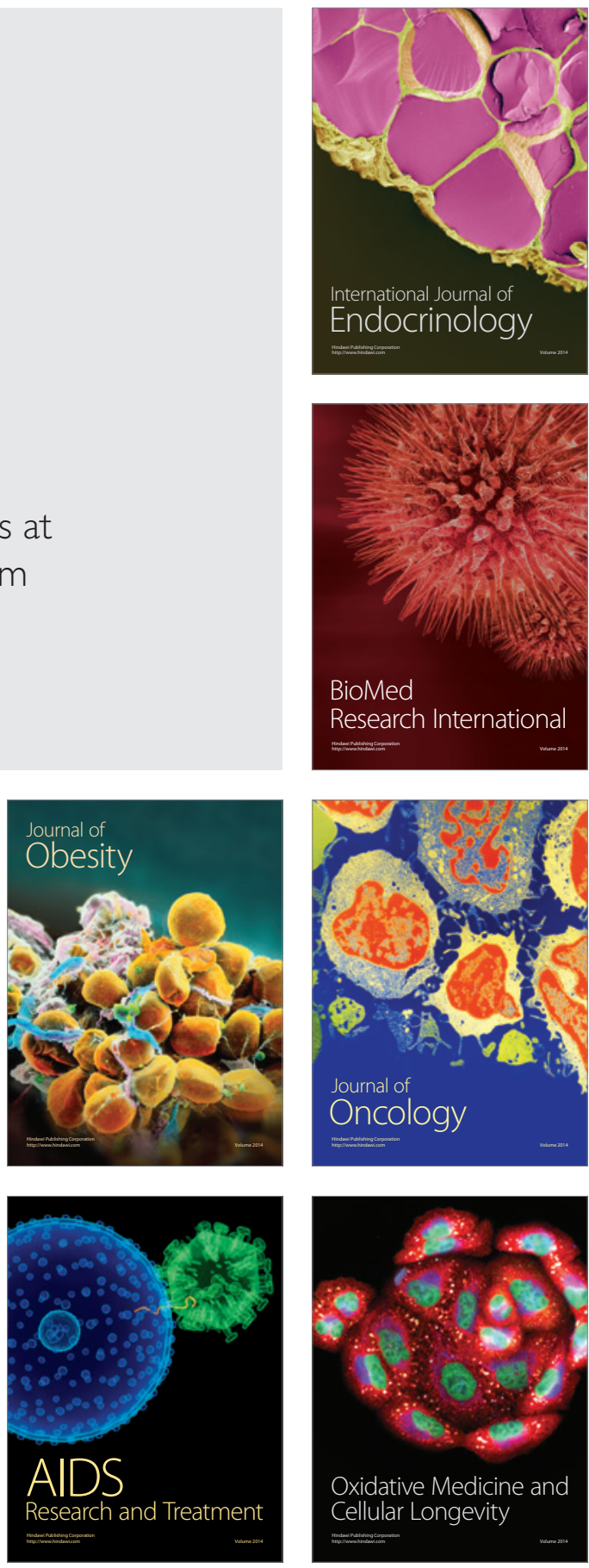